\title{
Blogging the Iraq War: Soldiers, Civilians and Institutions
}

\begin{tabular}{c} 
Alisa Miller \\
King's College London \\
\hline
\end{tabular}

\section{ABSTRACT}

This article considers how blogs written about the war in Iraq that began in 2003 have informed public narratives. It examines how so-called citizen journalists were read and presented by established media organisations. It considers what motivated some of the more influential bloggers of the war to engage in life-writing in this particular media, and how they found, read and responded to one another. It details how institutions like the US military reacted to milbloggers, shifting from a phase emphasising discretion and in some instances overt censorship, to viewing them as allies, implicitly and explicitly advancing a view of the war that circumvented critical, civilian media filters. It looks at the balance of coverage of mil and civilian bloggers in the West, and how they and their readers communicated-or failed to communicate-across cultures. Finally, it poses questions about how mediated content complicates notions of "authentic" war writing.

Keywords: Iraq war; milblogs; war blogs; censorship

\section{INTRODUCTION}

There are many problems implicit in assessing a recent conflict from the perspective of a cultural historian. The Iraq war that began with the invasion of United States-led forces in March 2003 is particularly challenging. A sub-theatre of the broader so-called "War on Terror" that has consumed 
the United States, its allies and enemies since the attacks on New York and Washington in September 2001, its representation is nebulous and contested. The war was orchestrated by an administration that dismissed questions about the legality of its actions and, as Joan Didion characterized Vice-President Richard ("Dick") B. Cheney's representative approach, 'would not then or later tolerate any suggestion that the story he was building might rest on cooked evidence'. ${ }^{1}$ As a result, public discourse about this war-from its compromised beginnings to the still-violent and uncertain present-remains active, relevant and dynamic.

The digital imprint of the war comprises a wealth of institutionally logged and independently created and maintained (or not) material. Some of this is semi-hidden and potentially non-recoverable to the historian: for example, the private and personal Facebook posts of soldiers and civilians. Some digital sources-the now-infamous images of torture and degradation at Abu Ghraib prison, and the videos of Saddam Hussain mounting the gallows that were captured on mobile phones and broadcast to the world on the Internet and on television-have become central to the public narrative and memory of the period. Blogs about the violence in Iraq are laden with such digitally processed, tagged and shared fragments, around which personal narratives and audience reactions or comments coalesce.

This article considers Iraqi war blogs within a tradition of life writing about war experience and violence, and how this accrues to build up public narratives. The medium for expression is central: its temporality and accessibility (or, for some would-be participants, inaccessibility) must be taken into account. But as important to this assessment is the open question of how the digital world reinforces and on rare occasions transgresses binaries: public and private, soldiers and civilians, institutions and individuals, perpetrators and victims. In the digital space, "small stories"- traditionally presented as departures from 'canonical' or 'big' stories'-have come to serve as a 'frame of analytical reference' for readers. ${ }^{2}$ Competing narratives, be they fixed or fleeting in their digital incarnations, produce hierarchies of suffering that reinforce personal and institutional lenses. Thematic commonalities, implicit in the act of storytelling in the digital form, do occasionally emerge, even as the implied battle between narratives and narrators to secure status as authentic chroniclers persists. What follows is an attempt to consider how institutions in the West, and in particular the US, have reacted to the increasing number of accounts produced, read and reused-in real time-by civilians and soldiers, and to examine how these blogs negotiate the tensions between institutional and individual testimony and memory. 


\section{INSTITUTIONS AND (UN)MEDIATED NARRATIVES}

During the early years of the Iraq war the various parties charged with controlling the flow of information about the conflict struggled to keep up with disparate, independent accounts. Despite-or because of-the amount of material generated by and available to the public, leaders were unable to justify or explain the direction of the Iraq war and occupation to large segments of their domestic populations and key allies. In the US, military officials, policy makers and the media establishment struggled to fully articulate the costs and commitments required to achieve even an ill-defined ideal of victory in Iraq, feeding a larger anxiety about national morale and purpose. Addressing Raymond Williams' writings about culture $^{3}$, Christopher Coker has analysed this unease with respect to twenty-first century Western military theory, and how it has been applied to the 'small wars':

Today the barbarians can attack the opulent, as they did on September 11, 2001...Western armies have been beaten by poorly armed, poorly trained foot soldiers who have made up for what they lack in arms by the spirit with which they fight. In the streets of Mogadishu and Beirut, the Americans encountered a people whose cultural capital stood them in good stead. The Americans were chased out by their superior morale and tenacity of purpose.

The malaise was not just tactical or strategic: 'It was they (the Americans) who lacked the "human factors" that Clausewitz tells us allow armies to prevail in battle: courage and hatred being chief among them.' The emphasis on soft power, 'cultural capital' and on a creating convincing war stories increased, and was seen to involve 'more than technical ingenuity, though the West is not always willing to acknowledge this in an age when its own way of warfare has become almost purely instrumental and when reliance on technology, not will or courage or stamina, has never been more pronounced.' ${ }^{\text {H }}$ With the emergence of digital communications platforms maintained outside of official infrastructures, soldiers and civilians became increasingly important, acting as agents in their own stories as well as in emerging public narratives.

In 2003 Iraq war blogs began emerging from the vast, bubbling sea of the internet, providing an alternative or supplementary source of orientation and information for participants in, and followers of, the conflict. Vivienne Jabri has written about the nature of the mainstream coverage of the early stages of the war, and how it reinforced disparities and the 
sense of existential distance between coalition forces, Western viewers and Iraqis:

\begin{abstract}
Across the globe, the images that will be remembered are those of overwhelming night-time aerial bombardment of a capital city, with persistent second-by-second explosions that lit the darkness of the metropolis below. The 'shock and awe' tactics celebrated by their perpetrators in the Iraq invasion were not simply aimed at the defeat of a spent regime, but rather at a global public gaze, a display of overwhelming power the immediate target of which was not just the high-density population of the city, but the Middle East as a political region and the global population as a whole. ${ }^{5}$
\end{abstract}

Despite the othering perpetrated by this narrative lens, the coverage also created a space for a counterpoint to performative technological military might to emerge: human stories on the ground. One Iraqi blogger, 'Salam Pax', offered up his story as a sustained critique of the lack of attention afforded the war's civilian victims by Western media platforms, detailing the various ways in which they were silenced. Reflecting on the scarred landscape of Baghdad, and specifically on damage to communication infrastructures that connected Iraqis to one another and a potential global readership, he returned to one of his older blog posts from March 2003. There he described the damage to the Ma'amun telephone exchange done by Coalition bombs: "now there are areas in Baghdad which we can't call and phones from/to abroad are pfffft, I have lost all hope that I will have internet again'. In March 2009 he reported that 'There is nothing now where this [the exchange] used to be. And most land line telephones in that area still don't work six years after this building was bombed. ${ }^{6}$ In 2003, damage to transportation, sewage and communication systems caused by the initial barrage was extensive, leaving scars on the landscape described by local bloggers, but not so much so that it cut would-be war narrators off from their digital tools and prospective audiences. The electricity remained on in Baghdad and elsewhere, military personnel maintained (relatively) regular contact with their families back home, civic culture continued to function, if under enormous strain: a full breakdown of society forcing the singular 'crisis' that 'produces real change' never occurred $;{ }^{7}$ Salam Pax managed to secure an international-if selective-following.

As an already acrimonious war and subsequent occupation grew worse, military and civilian life limped along, and competing narratives between occupiers and the occupied emerged. The military spectacle dominated, even as some details about the culturally offensive methods of the coalition forces-who searched the bodies of women and homes, used sniffer dogs, and publicly humiliated Iraqi elders and notables-were recounted 
digitally by invaders and the invaded alike. This contributed to the sense of fury and failure on all sides, and in turn helped to fuel the sectarian insurgency. Their subsequent attacks, coupled with a sense of steadily increasing violence and corruption, exacerbated coalition soldiers' and Iraqi civilians' frustrations about their mission and progress, feeding a vicious loop of distrust, disappointment and cruelty, ${ }^{8}$ as well as a need to articulate their varied experiences of sustained, raw human conflict.

\section{NETWORKS AND FILTERS}

During the invasion of Afghanistan, war blogs had emerged as a means for 'citizen journalists' to humanise the spectacle of war and to provide alternatives to institutional narratives. ${ }^{9}$ Formally, as testimonials, blogs were initially received as an extension of the long-established war journal, diary or letter, which in some cases informed or became a war memoir. They exhibited a variety of shared properties with analogue forbears in how they articulated 'life matter', including what Lilie Chouliaraki has identified as their 'textuality, diaologicality and temporality'. ${ }^{10}$ As immediate accounts and potential literary sources, they folded unproblematically into the emerging historiography of the conflict.

To an extent, the continuities and general acceptance of the war blog persisted as the War on Terror expanded geographically. However, by the time of the Iraq invasion, the capacity of blogging software expanded to allow for comments and the development of technologies such as RSS created the means for digital conversations to take place across time and space, in real time. War blogs and blogs utilising these functions transformed from simple chronological accounts with lists of links to mediated spaces that were implicitly and explicitly interactive and dialogical. ${ }^{11}$ Soldiers might detail their experience of a particular battle or encounter, even as their families, veterans and civilian commentators thousands of miles away reported on local, national and international coverage, and Iraqi civilian bloggers shared their perspectives on the event. In theory, this created the potential for more nuanced, collaborative accounts of what was happening to emerge in the short and medium term. In practice, divisions-both institutionally imposed and organic in nature-formed.

In the US, the number of individuals who directly experienced the Iraq war is relatively small when compared to the population that observed and engaged with it digitally or otherwise; in Iraq and the Middle East, the number is, it goes without saying, much larger. Yet in terms of which examples of life writing came to be recognised in the Western, and in particular the US media narratives of the war, 'milblogs' 
and 'milbloggers' - that is, active or retired soldiers ${ }^{12}$ —emerged as a significant narrative force. The historian and former airman Samuel Hynes has written about what he calls the 'secret society' of those who served or experienced war directly: 'Our secret made us different from those who were older or younger than ourselves, or who were not in the war. ${ }^{13}$ Blogs provided a way of representing the lived experience of the war-constructed through the secret society's particular cultural and gendered ${ }^{14}$ conventions- that circumvented the civilian press filter.

Traditional media sources amplified the sense that the milblogging community provided an authentic, unfiltered view of the war, encouraging its growth. For example, Time directed its readers to the 'loads of links to reports from writers embedded with the troops' captured on cyberjournalist.net and at daypop.com, a blog-specific search engine which in a search for "Iraq" in March 2003 turned up over 2700 entries. ${ }^{15}$ As the scale of the community attracted attention, informal but influential communications loops were established, and (sometimes) acknowledged. From Mosul in June 2004, responding to the grassroots reputation of blogs, one soldier at My War wrote that 'I found out about this blog website stuff in an article that was printed in the new Time magazine. It sounded like a good way for me to kill some time out here in Iraq, post a little diary stuff, maybe some rants, links to some cool shit, thoughts, experinces [sic], garbage, crap, whatever. I have no set formula on how i'm going to do this, i'm just going to do it and see what happens. ${ }^{16}$

These digital warriors became increasingly well-organised and connected through emerging and unofficial networks, capable of disseminating and/or correcting official verified and unverified stories and opinions.${ }^{17}$ That in the opinion of many milbloggers the broader military and the mainstream media (or "MSM") failed to sufficiently adopt their rhetoric or feature stories of heroism fed a sense of grievance and righteous purpose, and played to the perception that an unbridgeable gap had opened up between soldier and civilian narratives. The latter were characterised as mere speculators, whereas milblogs were 'given to readers as expressive of a kind of truth or from the moral high ground of lived professional experience'.$^{18}$ Blogging became an extension of the military mission, with milbloggers as the ultimate 'viable actor' with a mandate to transgress what traditionally 'cannot be said and what cannot be shown' in the public sphere. ${ }^{19}$

Even as they presented themselves-and were presented by traditional media-as independent voices, milbloggers recognised the potential to amplify their messages. By self-organising in the digital sphere, attracting key gatekeepers, and capturing new audiences with the potential to influence public opinion, they directed reader traffic to the edges of 
established hubs, which in turn spawned additional communities with their own narratives of the war. One described his path to digital notoriety via right-wing radio:

\begin{abstract}
First you travel to a war-torn Middle East country. Then one day you are minding your own business and people you don't know start lobbing mortars in your general direction in a concerted effort to separate you from the physical work and force you to assume room temperature. Later, in an effort to ease the severe shakiness that comes with an extreme adrenaline overdose, you sit down and write about it in your blog that gets approximately 6 hits per month. Then the whole world starts logging into your blog within .005 microseconds of Hugh Hewitt reading your post on his nationally syndicated radio talk show. Then you begin to panic because, come on, look at all those hits! ${ }^{20}$
\end{abstract}

Eventually, thousands of milbloggers, including not just soldiers but parents, spouses and veterans, and even news consumers commenting on what they were watching on television and the internet, came to be aggregated by Milblogging.com. The platform was created by software analyst Jean-Paul Borda, who started his blog The National Guard Experience while deployed in Afghanistan, and subsequently founded the site because 'You hear so much what's going wrong. It gets hard to hear after a while when there's so much good going on'. ${ }^{21}$ This infrastructure helped to ensure audiences and sustainability-'connectivity is the key', ${ }^{22}$ even as sifting through the material remained a challenge for those wishing to discover new voices more organically.

Given the scale of the life writing on offer, some siloing became inevitable. The blog Army of Dude wryly acknowledged the variety of sites on offer and the politically-charged networks they implicitly or explicitly served, linking to fellow bloggers' sites organised (sometimes ironically) under headings: 'Inform Yourself', 'Tax and Spend Defeatists' and 'Gun Clinging Fundamentalists'. ${ }^{23}$ Most bloggers asserted some editorial authorityfor example, sites like The Sandbox ${ }^{24}$ and BlackFive ${ }^{25}$ included posts from a variety of sources-even as more advanced technological resources for sorting material emerged.

Civilian war blogs, and specifically Iraqi bloggers, received less coordinated support from dedicated aggregators, securing traffic by more traditional means as bloggers and journalists nudged potential readers to their work via mentions and links. They in turn provided lists of additional blogs to follow, either for their perceived excellence or ridiculousness. Riverbend became one of the major English-language bloggers offering a civilian, Iraqi-centric and inflected critique of the US-dominated media narrative of the war. She recommended Back to Iraq, Dear Raed, Turning 
Tables, and Raed in the Middle, among other news sites (including the New York Times) she frequently critiqued; acting as gatekeeper, Salam Pax posted the following in June 2003: 'ladies and gentlemen, please welcome the Iraqi WOMAN blogger Zainab. Zainab has posted her first entry on [realwomenonline.com], she is not one of my friends and I have only met her two weeks ago, she found the idea of writing online interesting. I am eager to know what she will write as everyone else. go read her now. ${ }^{26}$ While these civilian networks remained comparatively ad hoc, in the US, sites like Technorati began aggregating commentary about the war not only by name but by political position. From these complicated critical media systems, combining assessments of bloggers, readers and established media institutions and search engines and ever-shifting cluster, or canon, of Iraq war blogs emerged.

\section{MILBLOGS}

It was acknowledged that the near-immediate access blogs created could prove logistically problematic for military security. Unlike in early twentieth century wars, when official censorship was broadly viewed as a necessary safeguard, in 2003 institutions grappled with how to address security concerns in an era when the policing of personal expression was viewed with intense hostility by a broad section of society. ${ }^{27}$ This was true of efforts to block the digital expressions and records of both military personnel and civilians. Legally, in the case of Iraq, some protections were formally guaranteed for all parties, which was recognised officially as an occupation by the United Nations, with expectations about the requisite human rights guaranteed in the Geneva Convention. ${ }^{28}$ The idea that the invasion and occupation were justified as spreading freedom and stability to the Iraqi people increased the pressure for evidence of the establishment of an increasingly liberal and secure social order to inform the 24-hour news cycle. This was demanded by vested interests across the political spectrum: from soldiers and their families wishing to cast their mission in a positive light, to journalists, the pro and anti-war movements in the US and abroad, international observers and Iraqis, all of whom were trying to understand whether the collective and individual suffering would be rewarded with meaningful improvements.

Despite their perceived independence, broadly speaking milbloggers produced material reinforcing general official themes and expectations about communication between the front and homefront, as well as advice for new arrivals to the region. This practice was established early in the history of milblogging. In Afghanistan, Belgian soldiers accessing mainly French and American milblogs found that they provided a "major source 
of information' and 'helped to compensate for some of the weaknesses of pre-deployment training. ${ }^{29}$ Swedish soldiers' blogs reflected the core values of the national mission: 'solidarity and humanitarianism'. ${ }^{30}$ US milbloggers and allies exposed to direct combat mostly offered up stories reinforcing ideals of unit loyalty and reverence for the military dead. The milblog BlackFive defined its 'Tenets' as follows: 'Supporting the Military; Caring for the Wounded; Remembering the Fallen; Honoring the Sacrifices. ${ }^{31}$ Many milblogs were underpinned by a belief in the rightness of their cause: 'It's very fulfilling to be a part of something so big and to play a role in the freeing of an entire nation. ${ }^{32}$

Some of the more extreme positions articulated in milblogs concerned military communications officials, in particular those concerned with influencing international opinions about the US military and its behaviour in Iraq. The Abu Ghraib images emerged as the most damaging example of private content that undermined the public honour of the mission, but other practices exposed the failure to bridge divides. For example, US milblogs only exceptionally acknowledged the suffering of civilians they encountered: as Mojo of the blog Turning Tables put it, the fact that 'they are dying here...these people...humans...us..... ${ }^{33}$ Instead as the occupation dragged on, some milbloggers came to view themselves not only as witnesses chronicling personal experience of the war but as self-proclaimed digital warriors battling critical discourses at home and abroad. Their sense of righteousness was compounded by the Islamophobia that prevailed in private and public discourse in the United States and Europe at the time: each individual act of violence committed by an Iraqi insurgent or militia recounted in the milblogosphere and consumed by the readership contributed to the narrative-appealing to many-of a holy war. ${ }^{34} \mathrm{As}$ the occupation dragged on, the sense of grievance grew, leading to overt criticisms of US - and US-supported Iraqi-military policy that revealed a failure of understanding and empathy the 'other' they worked alongside: 'I serve as an advisor to the Iraqi Army. These people don't take the war seriously. It is all about what the U.S. can give them.. ${ }^{35}$ In this blogger's unchallenged telling, the sacrifice of American personnel was far and away greater than that of Iraqi colleagues or the civilian population.

\section{CENSORSHIP}

For all their potential extravagances, milblogs constituted rich if challenging 'communications channels' that could be mobilised for a variety of purposes: from recruitment campaigns to countering public demands for greater transparency and accountability. ${ }^{36}$ In terms of basic affordances, coalition commanders recognised the need to enable 
digital communication between deployed personnel and their families, but feared a total lack of control of the various public sites. In April 2005, the Headquarters of the Multi-National Corps-Iraq issued a short memorandum, 'MNC-I Policy \#9' concerning 'Unit and Soldier Owned and Maintained websites', signed by John R Vines, Commanding Lieutenant General for the US forces. This stated that 'personal web sites and web logs produced in a personal capacity and not in connection with official duties need not be cleared in advance.' However, it went on to remind personnel that security dictated that 'prohibited information' be carefully considered, and that 'Risks of the release of information must be weighed against the benefits of publishing on the Internet.'

The vagueness of the policy and the pace of technological development with respect to new platforms led to more stringent attempts to disrupt too-specific narratives produced by individuals and units, specifically Army Regulation 530-1: Operations Security (OPSEC), issued in April 2007, which ordered soldiers to stop posting to blogs or sending personal emails without clearing their content with a superior officer. The US Department of Defense (DOD) subsequently shut down milbloggers' access to various video- and photo-sharing websites, including MySpace and YouTube, used by soldiers to narrate their experiences. These moves were noted by the mainstream press, including in emerging technology circles, which had warned of the potential for over-regulation of the digital sphere. In August 2005, Newsweek published its article on the ongoing debate under the byline: 'War on Milblogs'. ${ }^{37}$ Wired released a series of articles in 2007 and 2008 about the 'Kafka-esque turn', observing sadly that the 'secret-keepers have generally won the argument, and the oncepermissive atmosphere has slowly grown more tightly regulated. Soldierbloggers have dropped offline as a result'. ${ }^{38}$ Signalling the emerging hierarchy within the blogging community as well as an ongoing distrust of institutional intentions, Wired quoted 'milblogger supreme BlackFive' Matthew Currier Burden as observing that 'this reg will accomplish the exact opposite of its intent' as those wishing to 'fly under the radar and post negative items about the military, mission and commanders will continue to do so. ${ }^{39}$

Criticism about potential censorship and attempts to sanitise blogs were countered by visible support from political figures, including President George W. Bush who, the Washington Post reported, appeared via videolink in May 2007 to thank a room full of milbloggers for their service to the country. ${ }^{40}$ In February 2008, Lt. General William B Caldwell IV-a senior officer blogging on Small Wars Journal-reflected on how military personnel should be supported in engaging with new media, orientating his thoughts around four keywords: 'Encourage', 'Empower', 'Education' and 'Equip'. He argued that 'we need to encourage Soldiers to "tell/share 
their story"'. This was necessary to counter the "widely held perception that media coverage of the war in Iraq is negative.' He argued that this was not the fault of the media but was a response to the public's 'voracious appetite for the sensational...the train wreck in progress'. However, he noted, 'they also have a very strong desire to hear their [soldiers'] personal stories. They want to know what it is like, what the Soldiers are experiencing, and how the Soldiers feel about their mission. That is why we must encourage our Soldiers to interact with the media, to get onto blogs and to send their YouTube videos to their friends and family.' The effect, he concluded, is then 'overwhelmingly positive'. ${ }^{41}$ Wired noted that his opinion ran counter to risk-averse policies designed to limit communication, as well as the implicit bias towards a positive view of the Iraq war: 'Leaders need to understand and accept that that not all media interactions are going to go well. ${ }^{42}$

Some were less risk-averse than others. Writing about his attempts to circumvent the military's tendency to complicated communications processes and to allow soldiers to "think outside the box ${ }^{\text {'43 }}$, Steven J. Alverez, who served as a senior Public Affairs Officer in Iraq, wrote of his pleasant surprise when he reported to Gen. David Petraeus about the blog he had been publishing in the Orlando Sentinel, whose only advice was to 'keep it honest'. ${ }^{44}$ In practice, official responses remained inconsistent, and open to criticism about just what the military was willing to allow its personnel to communicate. Jason Hartley blogged satirically on www.justanothersoldier.com about loving dead civilians with the aim of highlighting what he saw as the US military's disregard for Iraqi casualties; he was demoted from specialist to sergeant. ${ }^{45}$

The debate about censorship and disclosure took place among lowerranking milbloggers as well. On his site A Line in the Sand, Chris Missick, a soldier with the Army's $319^{\text {th }}$ Signal Battalion, reflected on the risks and opportunities associated with blogs. He recognised that:

\footnotetext{
Never before has a war been so immediately documented, never before have sentiments from the front scurried their way to the home front with such ease and precision. Here I sit, in the desert, staring daily at the electric fence, the deep trenches and the concertina wire that separates the border of Iraq and Kuwait, and write home and upload my daily reflections and opinions on the war and my circumstances here, as well as some of the pictures I have taken along the way. It is amazing, and empowering, and yet the question remains, should I as a lower enlisted soldier have such power to express my opinion and broadcast to the world a singular soldier's point of view?
}

Missick was writing in the aftermath of the release of images of US soldiers abusing Iraqi prisoners at Abu Ghraib, which had 'cratered America's moral high ground, and demonstrated how even a superpower could 
be blitzkrieged by some homemade downloadable porn'. The Wired article that reprinted Missick's post noted that he had gotten to the heart of the dilemma 'of the potential of free speech in a war zone'. The publication also noted that his blog eventually logged 'somewhere north of 100,000 pageviews. No blogging record, but rivaling the wonkish audience for the Pentagon's daily briefing on C-Span or DOD press releases. ${ }^{46}$ Milbloggers-sometimes aided by, and sometimes despite institutional interventions-were succeeding in securing a significant public voice.

\section{CITIZEN JOURNALISTS}

Like military officials, journalists and major new media organisations also came to recognise the opportunity Iraq milblogs presented as immediate and compelling first-hand narrative material, even as they considered the disorientating and potentially undermining effects of self-published digital accounts of the war being offered and consumed in real time. Reflecting on not just war blogs but the broader nature of participatory journalism and media in a series of papers published in 2003 for the Media Centre at the American Press Institute, Shayne Bowman and Chris Willis acknowledged the emerging sense of dislocation as traditional journalists found that their "hegemony as gatekeeper of the news is threatened by not just new technology and competitors but, potentially, by the audience it serves. ${ }^{.47}$

Journalists representing established news organisations like the BBC and the Christian Science-Monitor adapted their dispatches to reflect the attributes of independent bloggers, whose 'diary form', written 'piece by piece' adds 'further emphasis to the impression of everyday reality and the diarist's integrity...So the formal impression of the process of writing in the diary form is more than an impression in the blog form: here the process of writing and the process of reading $d o$ unfold side by side. ${ }^{48}$ Hence, the form-part of a larger blog culture appealing to a range of communities-seemed to justify itself, even as it addressed public demands for personalised forms of news. The authenticity implied appealed to media organisations attempting to manage the broader narrative of a war whose very origins were considered by many to be compromised, not least by press mis-reporting of the intelligence and motives underpinning the US-led invasion. Hence the emergence of coordinated efforts-in the US context, the 'Blog.gov' phenomenon-which attempted to inject a sense of humanity and transparency into institutions ${ }^{49}$, and disparate but influential attempts to counter mainstream press marginalisation of the antiwar movement, as exemplified by the efforts of, for example, the policy blog the Daily Kos. ${ }^{50}$ 
The response from the established media was not to censor or disregard bloggers, but to adopt their life writing tactics. Furthermore, the exceptional place the military had secured in civic society in the US in particular largely limited critical engagement with milblogs-even when they contained inaccuracies or overt political biases. Even the acknowledgement of structural challenges and problems associated with digital communications platforms in the popular media was muted. Mirroring the ways in which photographs were once presented as the ultimate medium for truth telling in war, ${ }^{51}$ James Hider argued in The Times in October 2004, milblogs were 'telling it like it is on the frontline'. ${ }^{52}$ It would not do for the institutional media to be seen to be questioning the soldier's voice, particularly as readers came to view blogs as presenting a more authentic-if not necessarily a more balanced-story of the war..$^{53}$

Journalists reporting on the rise of milbloggers stressed their value as potential insider, eyewitness sources capable of circumventing official military channels. In March 2003 CNN acknowledged new digital life writing about the war articulated by independent voices on 'www.blogsofwar.com, www.sgtstryker.com and www.lt-smash.us', which it noted had become 'a popular alternative news source...sometimes beating newspapers and television with war developments'. ${ }^{54}$ They argued that blogs addressed traditional needs not specific to the Iraq war, but characteristic of communication between fronts and home fronts throughout history. For soldiers, milblogs provided 'A modern twist to war journals' $:{ }^{55}$ they 'could send letters home to friends and relatives in a single dispatch. They could mock commanding officers in ribald, and anonymous, prose. They could describe combat with the immediacy of Ernie Pyle, without the filter of actual editors. ${ }^{56}$ Such an assessment downplays the extent to which war writing, and indeed all writing, is mediated in cultural ways-through films, fiction, video games, adherence to genres and inherited forms, military training and so on-however much readers wish to achieve the 'idealised end' of 'proximity to experiences of war' through soldiers' and veterans' life writing. ${ }^{57}$

Initially enthusiastic journalists and media observers argued that the digital audience, responding to the blogger in real time, provided not only an appealing, saleable hook; it ensured a 'self-correcting process' wherein different points of view were provided by readers, countering a tendency for self-referencing in diary-like entries: the 'Daily Me' as opposed to the 'Daily We'. ${ }^{58}$ However, even as the traditional media reported on the rise of bloggers in cautiously optimistic terms-as empowered independent voices-and as the scale of the pundits' and in particular milblogs grew to form counter-empires of their own, replete with their own infrastructure and institutional sponsors, there slowly emerged an awareness of the problems inherent in presenting war blogs as pure "sources", as opposed 
to content that, in addition to cultural factors, was mediated through layered technical and editorial filters and aggregators. This was perhaps inevitable with respect to the Iraq conflict which was so politically divisive, but in a desire to encourage participatory journalism many media commentators underreported the extent to which life writing on blogs was fragmenting, and conversations-on all sides-were increasingly filtered. With so much material to consider, and with cultural moderators as well as software that helped to predict and even drive tastes and aggregate common themes becoming ubiquitous, bloggers and their readers could - if they so wished, and often they did wish-simply respond and add to an ever-growing amount of edited content that affirmed their assumptions and experiences. ${ }^{59}$ Furthermore, in ceding war reporting to citizen journalists self-publishing on the web, and positing a 'utopian misunderstanding that denies a place for expertise' and 'informed judgement' ${ }^{60}$ traditional journalists undermined their role as careful, considered arbiters of the war's official and humanitarian narratives.

The effect of this was the emergence of a popular consensus about the fading of balanced narratives. Civilian bloggers writing within Iraq and the US-and some milbloggers on the ground, including for example Michael Yon ${ }^{61}$ — criticised the military bias of the supposedly neutral Western press establishment. They felt that mainstream news sources were failing to capitalise on the nuanced material they were providing. This was compounded by the sense that critical assessments in the US and abroad had been muted in the run-up to the war, including in the supposedly independent blogosphere, owing to 'the fear of being branded anti-patriotic or a foolish apologist for dictators', the 'nervous self-hatred of an intellectual class' and an 'unsophisticated theory of media bias. ${ }^{62}$

In Riverbend's assessment on Baghdad Burning, laziness and myopia in US and Western coverage were crushing nuance and making it extremely difficult-even in the digital space-for effective, compassionate conversations to take place between soldiers and civilians on all sides: 'Bush was wrong when he said, "You are either with us or against us." The world isn't in black and white - there are plenty of people who were against this war, but also against Saddam. They aren't being given a chance. Their voices aren't heard because they weren't in Washington or London or Teheran. ${ }^{\prime 63}$ In 2003 Time directed its readers to one Iraqi blogger-'Salam Pax', who posts 'poignant first-person reports on the web' and 'appears to be the real thing'-alongside three US milblogs, seven pundit sites and three blogs offering military analysis. ${ }^{64}$ The New York Times blog 'At War', presented as a 'reported blog from Afghanistan, Pakistan, Iraq and other conflicts in the post-9/11 era' that provides 'insight — and answers 
questions - about combatants on the faultlines, and civilians caught in the middle ${ }^{65}$, had in the period no Iraqi (or Afghani or Pakistani) contributors, focusing on topics including veterans' suicide and recovery, healthcare, and the integration of women into the military.

To an extent, bias in the MSM was the default charge levelled by most independent bloggers whose writings were not picked up and infused into the broader public narrative of the war: everyone felt that the important stories-their stories, specifically-were not being told to a large or influential enough audience, let alone influencing policy or practice. Criticisms of the established media, particularly with respect to volume and balance, came from all sides. Riverbend complained in July 2004 that 'Dozens of Iraqis are dying on a daily basis in places like Falloojeh and Najaf and everyone is mysteriously silent-one Brit, American or Pakistani dies and the world is in an uproar-it is getting tiresome. ${ }^{66}$ In 2006 BlackFive complained to the Wall Street Journal: 'Does Abu Ghraib need to be told 40 times above the fold in the New York Times when half your readers couldn't name the guy who won the Medal of Honor? ${ }^{27}$ With so much mediated material and commentary available to writers and readers alike, achieving public reports that acknowledged the humanity and perspective of all parties affected by the war, and weighted official narratives accordingly, became more and more difficult.

\section{WALLS}

Bloggers chronicling life and war do so for a variety of reasons, but implicit in their efforts of recording is an expectation that the reader will recognise the humanity of the author and his or her subjects, and sympathise with their accounts. And yet the complexities of perspective and the prejudices of writers and audiences often derail attempts to communicate, particularly across military and civilian divides. Barriers of understanding, empathy and temporality emerged between many, if not all Iraq war bloggers. This is not a new phenomenon of the digital age: Stephen Spender, in reaction to the Allied occupation of post-Second World War Germany, 'became exhausted by the scale of ignorance on both sides.' In war, and after, everyone displayed a capacity for disdain, especially when they were confronted with seemingly passive suffering: 'Several officers told him that they sympathised with the Nazis because they were fellows who stood up for their country, whereas the refugees were rats who had let their country down. ${ }^{68}$ The US milblogger Brad P. Lewis used a similar language to frame the tenacity and commitment of fellow soldiers in Iraq, 
noting 'the little things they willingly give up, to live and work in a rat hole. ${ }^{69}$ Lewis had written earlier-seemingly unselfconsciously, on active duty as a member of an occupying force-of his anger at being attacked by insurgents 'while you are minding your own business'. ${ }^{70}$ Blogs did not solve very human failures, including the inability to see one's self from alternative perspectives.

The milblog Turning Tables attempted to breach the barrier between US soldiers and Iraqi civilians as Moja prepared to return home following his tour of duty. He writes about his desire to believe that the sacrifices on all sides had meaning: 'there are mass graves being unearthed...there are people digging through them...trying desperately to find long since gone loved ones...i can't even imagine...yes i can.... As he tried to imagine the horrors of the victims who could not leave, he consoled himself by returning the official line about why he was in Iraq in the first place: ' $i$ do think that iraq will one day be better...i do think that this country will enjoy basic freedoms...and i hope they will be able to take advantage of them... with out intervention from any outside source.... He acknowledged the overriding narrative that dominated US, and to an extent in the Western rhetoric, and had the effect of dehumanising Iraqi (and Muslim) victims of the War on Terror: 'they deserve it [basic freedoms] ...because they are not all terrorists/freedom fighters/militants/what ever...they are people... and they hurt...and they worry...and they sweat....and they work...and they provide as best they can...that's what we do...all of us... ${ }^{71}$

Iraqi bloggers also struggled to communicate the enormity of the experience of invasion and occupation, and sustained violence and destruction. Considering various literary and aesthetic outputs produced by Iraqis in response to the war, Nadje Al-Ali and Deborah Al-Najjar touch on the potential, but also the implicit difficulty of bringing new voices and perspectives to the forefront as they are filtered through international lenses and abstracted moral systems, stripped of specific cultural and personal contexts. 'How do we grieve something that seems to read like a lost object, a forgotten subject? How do citizens gather energy to oppose war when it seems far removed from the daily realities of paying bills and feeding one's family?' ${ }^{72}$ This was particularly problematic in the digital context, wherein audiences sampled narrative blogs, considering them primarily from a personal and/or political perspective. ${ }^{73}$ Riverbend recalled her paralysis after having been told a harrowing story by a nineteen-year-old woman about her detention at Abu Ghraib, where she witnessed several beatings and the rape of a male prisoner by one of the jailors, and where her mother and three brothers were still imprisoned: 'All I [Riverbend] could do was repeat, "I'm so sorry...I'm really sorry". In turn the woman 'shook her head and waved away my words of 
sympathy: "It's okay—really_I'm one of the lucky ones...all they did was beat me." 74

In theory, technological advances had the potential to shift the dynamic between the wars' various witnesses. In practice, the potential for exchange did not necessarily result in a sense of a diverse and sustained community of bloggers and readers, at least not one that could bridge the fundamental divides between soldier and civilians approaching the war from conflicting cultural viewpoints. Occasionally, the wall was breached, and a lasting connection was formed: in September 2003 Riverbend wrote that 'I've been following Turning Tables ever since someone pointed it out to me two weeks ago. "Moja" somehow puts a human face on the troops in Iraq. I read his blogs and look at the troops and wonder, could that be him? It's strange to read stories from the "other side"... I'm glad he's going to be able to go home, safely. ${ }^{75}$ In October 2014 Moja wrote about the emotionally layered experience of driving around Georgetown, being interviewed by a Guardian journalist about the war: 'we talked about the last year and where things have ended up...we talked about the cryptic hand signals used by american soldiers at iraqi check points...we talked about house music and military cultural awareness training...we talked about riverbend.... ${ }^{76}$

As time progressed, a feeling of dislocation became a common theme for bloggers considering the legacy of the war, with time to consider the silos that formed during the conflict, and persisted beyond it. One US-based milblogger reflected that, 'As close as we were then, both geographic distance and the rigors of post-military life have left us isolated. ${ }^{77}$ Physical therapist Adel Levine, writing for the New York Times blog 'At War' in 2016, detailed her continued surprise at how compartmentalised traumas reassert themselves. She blogged about attending a wedding of a co-worker at the Walter Reed Army Medical centre, where she encountered a former patient.

That I remembered his face, but not the fact that he was missing both arms and a leg at the groin, caught me totally off guard. Finding myself surprised by the extent of this young man's injuries-injuries that were routine for so many years-well, a light flickered in my brain. And suddenly, I was back there in our old clinic, surrounded by young men on treatment tables. $^{78}$

Even surrounded by colleagues with similar experiences of the war, she found herself isolated. Her blog presented her with a space to explore discontinuities and traumas stemming from her war experience, but not to transcend them. 


\section{GONCLUSION}

In these accounts, the self-or the blogger-remains at the heart of the narrative performance. However, with so much digital and analogue information and experience to hand, the writers implicitly address issues of temporal expansion and contraction. They hint at how the digital space, despite its great potential to offer up diverse accounts with the aim of fostering cultural exchange, global connections and considered communication, largely fell short of utopian expectations. More broadly, they expose faultlines in the capacity for digital encounters to transform consumption of information and imaginative connections to actual human empathy.

Writing about counter- and extra-institutional movements in art, music and publishing, Sarah Lowndes has argued that the 'global political situation shapes DIY activity now more than at any point in history, as social media networks spread information so rapidly. The idea of community, which once meant something local, now has an expanded meaning as online communities, which cross borders and time zones, form and act. The internet is the second place where we all now live, whether we are immersers, reluctant users or strategic abstainers. ${ }^{79}$ The extent to which Iraqi war bloggers represent independent, counter-institutional voices was initially overstated, both by the writers themselves and by traditional cultural mediators. Even in European nations sceptical about the US prosecution of the War on Terror, the recounting of 'routinized everyday' practices on milblogs-insufficiently balanced in Western discourses by accounts of and by the civilian victims of the war-ultimately reinforced establishment narratives and contributed to the 'militarization of civil society' ${ }^{80}$

For many bloggers the boundaries between life writing about war and institutional discourses eventually dissipated, mirroring a broader shift in war blogs being seen not as grassroots outliers but as multifaceted and mainstream. When Alex Horton of Army of Dude returned to the US, he struggled to make sense of his veteran's package, offered through the GI Bill. He catalogued his experiences on the blog, received help, and offered advice to fellow soldiers and veterans. He was ultimately offered a job-a 'new mission'-writing a new blog, VAntage Point, for the Department of Veterans Affairs. Horton acknowledged that 'Now that I work for the government (again), I relinquish a bit of editorial freedom of what I can say here. That's the downside to increasing the reach of my words.' However, as the project was conceived as a dialogue with topics suggested by guest posts addressing 'real issues', in his opinion the benefits outweighed any reservations about a loss of independence: 'with it I gain legitimacy and authority to speak about veterans' issues, and I have a hard time thinking of a better way to use my energy.' It was a natural 
extension-or relation-to Army of Dude, enabling him to help to build a new platform for meaningful exchange:

\begin{abstract}
Anyone can submit a post on a topic concerning veterans, and it will be published as long as it's coherent and competently argued. We're not just looking for fluff pieces either. If you had a bad experience with a VA doctor or couldn't get through on a help line, we want to hear about it. We're looking for a cross section of guest writers-anyone from a student struggling with reintegration to a VA surgeon to a Vietnam veteran and everyone in between. For the first time in the history of the Department of Veterans Affairs, ideas and communication will flow two ways.
\end{abstract}

Horton's view of his blogging had come full circle in that he could use and even expand institutional boundaries, without losing his particular independent voice: 'VA wanted me to write for them, and with me comes my style and personality unabridged.' ${ }^{\text {'1 }}$

In the ongoing discussions about the Iraq war, bloggers endeavour to keep some focus on their still-developing, if less urgently "newsworthy", narratives. This includes soldiers and the families of those still deployed in Iraq, as well as civilians and refugees who remind readers that 'we're still at war'. ${ }^{82}$ The digital infrastructure underpinning the work of war writers continues to offer potential opportunities for cultural exchange, with some limited examples providing hope of dialogue. As Riverbend wrote in her last post in 2013, 'For those of you who have been asking about me and wondering how I have been doing, I thank you. "Lo khuliyet, qulibet..." Which means "If the world were empty of good people, it would end." I only need to check my emails to know it won't be ending any time soon. ${ }^{83}$ At the same time, new publishers ${ }^{84}$ (Facebook, Twitter, YouTube, WhatsApp) provide mediated and, many argue, increasingly manipulated platforms that seem to limit, as opposed to encourage, thoughtful discourse across past and emerging battle lines. How writers construct and narrate experiences, and how online communities consume and simultaneously inflect "authentic" content within this digital world, remains contested by bloggers, readers and critics. Silos and divisions, born of real and imagined encounters, cultural barriers and distrust, persist. Out of this has emerged a more sophisticated debate about the apathy of 'virtual citizens' whose consumption of blogs and digital content more broadly 'shift into forms of passivity... [occluding] important changes in political and civic activity brought about by new media of networked communications'. ${ }^{85}$ Whether or not in time these digital conversations will, publicly and in any meaningful way, cross civilian and military lines to form new strands of the public narrative that fully reflect the lived experiences of the war, remains to be seen. 


\section{ACKNOWLEDGEMENTS}

This article has been made possible as a result of funding from the European Research Council (ERC) for the project 'Ego-Media: the impact of new media on forms and practices of self-presentation' [FP7/2007-2013; grant agreement No. 340331].

\section{WORKS CITED}

Al-Ali, Nadje and Deborah Al-Najjar. "Writing Trauma, Memory, and Materiality." Eds. Al-Ali and Al-Najjar. We Are Iraqis: Aesthetics and Politics in a Time of War. Syracuse: Syracuse University Press, 2013. Xxv-xl.

Allawi, Ali A. The Occupation of Iraq: Winning the War, Losing the Peace. New Haven: Yale University Press, 2007.

Alvarez, Steven J. Selling War: A Critical Look at the Military's PR Machine. Omaha: Potomac Books, 2016.

Benaissa, Amal. Blog.gov: 'Winning Digital Hearts \& $\mathcal{E}$ Minds? Professionalization, personalization and ideology in foreign policy communication. $\mathrm{PhD}$ thesis: London School of Economics, 2011.

Benevisti, Eyal. The International Law of Occupation. Oxford: Oxford University Press, 2012.

Bowman, Shayne and Chris Willis. WeMedia: How Audiences are Shaping the Future of News and Information. The Media Centre at the American Press Institute, 2003.

Brant, Martha. "War on Milblogs." Newsweek 2005.

Brennen, Bonnie and J. Scott Brennen. "Taking Our Pictures: Citizen photojournalism in traditional U.S. News media." Journalism Practice 9.4 (2015): 520-535.

Burden, Michael. BlackFive [blog]. 2003-2009. https://www.blackfive.net/main/.

Butler, Judith. Precarious Life: The Powers of Mourning and Violence. London: Verso, 2004.

Caldwell, Bill. "Changing the Organisational Culture (Update)." Small Wars Journal 2008. www.smallwarsjournal.com/.

Chouliaraki, Lilie. "Authoring the Self: Media, Self and Testimony in Soldiers' memoirs." Media, War and Conflict 8.4 (2016): 58-75.

CNN. "Soldier 'bloggers' report on war." CNN.com, 26 March 2003. www.edition.cnn. com/2003/WORLD/meast/03/26/sprj.irq.soldier.blogs.reut/.

Coker, Christopher. Waging War Without Warriors?: The Changing Culture of Military Conflict. London: Lynne Rienner Publishers, 2002.

Colby Buzell. My War: Killing Time in Iraq [blog]. 2004-2009. www.cbftw.blogspot.co.uk/.

Dao, James. "Military Blogging Goes Mainstream.” New York Times, 1 May 2011.

Dean, Jodi, Jon W. Anderson and Geert Lovink. Reformatting Politics: Information Technology and Global Civil Society. New York: Taylor and Francis, 2006.

De Fina, Anna and Alexandra Georgakopoulou. Analyzing Narrative: Discourse and Sociolinguistic Perspectives. Cambridge: Cambridge University Press, 2011.

Didion, Joan. "Cheney: The Fatal Touch." New York Review of Books 2006.

Feigel, Lara. The Bitter Taste of Victory: Life, Love and Art in the Ruins of the Reich. London: Bloomsbury, 2016.

Filkins, Dexter. The Forever War. New York: Vintage, 2008.

Fox News. "Milblogs' Present Iraq War from Military Point of View." Fox News 2006.

Friedersdorf, Conor. "Why So Many Early Bloggers Got the Iraq War Wrong." The Atlantic 2013. 
Garden, Mary. "Defining Blog: A Fool's Errand or a Necessary Undertaking." Journalism 13.4 (2012): 483-499.

Grim, Ryan. "Military BlogJam: Greyhawk." Politico 2007.

Gupta, Suman. Imagining Iraq: Literature in English and the Iraq Invasion. London: Palgrave Macmillan, 2011.

Hamilton, Anita. "Best of the War Blogs.” Time 2003.

Hellman, Maria. "Milblogs and Soldier Representations of the Afghanistan War." Media, War and Conflict 9.1 (2016): 43-57.

Hennessy, Cari Lynn and Paul S. Martin. "Blogs, the Mainstream Media, and the War in Iraq." Paper prepared for presentation at the Annual Meeting of the American Political Science Association, Philadelphia, PA, 2006.

Hider, James. "Milblogs: Telling it Like it is on the Front Line." The Times 2004.

Hockenberry, John. "The Blogs of War." Wired 2005.

Horton, Alex. Army of Dude [blog]. 2006-2011. www.armyofdude.blogspot.co.uk/.

Hynes, Samuel. Flights of Passage. London: Bloomsbury, 1988.

Johnson, Thomas J. and Barbara K. Kaye. "Believing the Blogs of War? How Blog Users Compare on and Characteristics in 2003 and 2007." Media, War and Conflict 3.3 (2010): 315-333.

Knickerbocker, Brad. "Soldier Blogs Bring the Front Line to Folks at Home." The Christian Science Monitor 2005.

Levine, Adel. "Combat Amputees, and Their Therapists, Find Roads to Happiness." At War: Notes from the Frontlines. New York Times 2016.

Lewis, Brad P. Training for Eternity. 2003-2018. www.chaplain.blogspot.co.uk/.

Lowndes, Sarah. The DIY Movement in Art, Music and Publishing: Subjugated Knowledges. London: Routledge, 2016.

Lytle, Tatum H. "A Soldier's Blog: Balancing Service Members' Rights vs. National Security Interests." Federal Communications Law Journal 59 (2007): 593-614.

Moja. Turning Tables [blog]. 2003-2006. www.turningtables.blogspot.co.uk/.

Munksgaard, Daniel. Warblog without end: Online anti-Islmamic discourses as persuadables. $\mathrm{PhD}$ thesis: University of Iowa, 2010.

Resteigne, Delphine. "Still Connected in Operations? The Milblog Culture." International Peacekeeping 17.4 (2010): 515-525.

Riverbend. Baghdad Burning [blog]. 2003-2013. www.riverbendblog.blogspot.co.uk/.

Roeder, George Jr H. The Censored War: American Visual Experience During World War Two. New Haven: Yale University Press, 1993.

Salam Pax. Salam Pax: The Baghdad Blogger [blog]. 2002-2009. www.salampax.wordpress.com/.

Schachtman, Noah. "Army Squeezes Soldier Blogs, Maybe to Death." Wired 2007. 'Top General: Let Soldiers Blog.' Wired, 31 January 2008.

Schwabb, Nikki. "Milbloggers Wary of New Policy." Washington Post 2007.

Schwarz, Michael. War Without End: The Iraq War in Context. Chicago: Haymarket Books, 2008.

Sontag, Susan. On Photography. New York: Farrar, Straus \& Giroux, 1977.

Spektor, Mike. "Cry Bias, and Let Slip the Blogs of War." Wall Street Journal 2006.

Stanford, David (ed.). The Sandbox [blog]. 2006-2014. www.gocomics.typepad.com/the sandbox.

Thompson, Garry. "Weblogs, Warblogs, the Public Sphere, and Bubbles." Transformations: Journal of Media E Culture 7 (2003): 1-11.

Usbeck, Frank. "'Keep the Fan Mail Coming': Ceremonial Storytelling and Audience Interaction in a US Soldier's Milblog." Saechsische Landesbibliothek- Staats- und Universitaetsbibliothek Dresden (2016): 149-163.

Wax-Thibodeaux, Emily. "Female Veterans Say it's their Time to Write the Memory of War." Washington Post 2018. 
Webster, Nathan S. "Running with the Big Boys' in Iraq, a Female Soldier Paves the Way." New York Times 2013.

Williams, Raymond, Keywords: A Vocabulary of Culture and Society. London: Croom Helm, 1976. Wolf, Hope. "Mediating War: Hot Diaries, Liquid Letters and Vivid Remembrances." Life Writing 9.3 (2012): 327-336.

Yon, Michael. Michael Yon Online Magazine. 2004. www.michaelyon-online.com/MichaelYon/Michael-s-Dispatches/.

\section{ABOUT THE AUTHOR}

Alisa Miller is based in the English Department at King's College London, where she is Research Associate and Project Manager for the ERCfunded Ego-Media and Beyond Enemy Lines. Her research focuses on the comparative development of war cultures in twentieth and twenty-first century Europe and the United States, looking at how evolving literary networks—utilizing different forms of media and technology-influence political discourses and perceptions of violence. Some recent publications include Rupert Brooke in the First World War (Clemson and Liverpool University Press, 2017) and 'Modern War and Aesthetic Mobilisation: Looking at Europe in 1914' in the British Journal of Military History (2016) Email: alisa.m.miller@kcl.ac.uk.

\section{NOTES}

1 Didion, Joan, 'Cheney: The Fatal Touch.' New York Review of Books, 5 October 2006.

2 De Fina, Anna and Alexandra Georgakopoulou. Analyzing Narrative: Discourse and Sociolinguistic Perspectives. Cambridge: Cambridge University Press, 2011 (121).

3 Williams, Raymond, Keywords: A Vocabulary of Culture and Society. London: Croom Helm, 1976.

4 Coker, Christopher. Waging War Without Warriors?: The Changing Culture of Military Conflict. London: Lynne Rienner Publishers, 2002 (108-109).

5 Jabri, Vivienne, 'Shock and Awe: Power and the Resistance of Art.' Millennium: Journal of International Studies [34.3] 2006, 819-839 (823).

6 Salam Pax. 'Blog Flashback: 26.03.2003.' Salam Pax: The Baghdad Blogger, 26 March 2009, www.salampax.wordpress.com/. Accessed 29 November 2017.

7 Schwarz, Michael, War Without End: The Iraq War in Context. Chicago: Haymarket Books, $2008(6-10)$.

8 Allawi, Ali A. The Occupation of Iraq: Winning the War, Losing the Peace. New Haven: Yale University Press, 2007 (186). See also Dexter Filkins, The Forever War. New York: Vintage, 2008 for, arguably, the best narrative account from the perspective of a US journalist covering the war.

9 Bowman, Shayne and Chris Willis. 'WeMedia: How audiences are shaping the future of news and information.' The Media Centre at the American Press Institute, July 2003.

10 Chouliaraki, Lilie. 'Authoring the Self: Media, self and testimony in soldiers' memoirs.' Media, War and Conflict 8:4 (2016) 58-75 (60). 
11 Garden, Mary. 'Defining blog: A fool's errand or a necessary undertaking.' Journalism $13: 4$ (2012) 483-499 (485).

12 This includes military personnel on active or inactive duty, their families and veterans, although this article focuses on soldier and veteran bloggers.

13 Hynes, Samuel. Flights of Passage. London: Bloomsbury, 1988 (vii-viii).

14 Because of limits placed on female soldiers with respect to deployment to forward positions, milblogs from the initial phases of the Iraq war were written from an almost exclusively male perspective. Only later did female soldiers start to be recognised for their service, and their life writing about war. See Nathan S. Webster, "Running with the Big Boys' in Iraq, a Female Soldier Paves the Way.' New York Times, 28 March 2013, and Emily Wax-Thibodeaux, 'Female veterans say it's their time to write the memory of war.' Washington Post, 30 March 2018.

15 Hamilton, Anita. 'Best of the War Blogs.' Time, 20 March 2003.

16 Colby Buzell. 'Blogging from a Combat Zone.' My War: Killing Time in Iraq, Tuesday 22 June 2004, www.cbftw.blogspot.co.uk/. Accessed 5 December 2017.

17 Grayhawk, blogging at The Mudville Gazette, rose to the forefront as one of the most vociferous voices proclaiming his independence and supremacy of vision as a 'libertarian', but numerous examples exist. See Grim, Ryan. 'Military BlogJam: Greyhawk.' Politico, 27 June 2007.

18 Gupta, Suman. Imagining Iraq: Literature in English and the Iraq Invasion. London: Palgrave Macmillan, 2011 (17). Emphasis in original.

19 Butler, Judith. Precarious Life: The Powers of Mourning and Violence. London: Verso, 2004 (xvii).

20 Lewis, Brad P. 'Removing a Blockage.' Training for Eternity, 2 February 2006, www.chaplain.blogspot.co.uk/. Accessed 8 January 2018.

21 John Paul Borda, quoted in Spektor, Mike, 'Cry Bias, and Let Slip the Blogs of War.' Wall Street Journal, 26 July 2006.

22 “'Milblogs” Present Iraq War from Military Point of View.' Fox News, 24 May 2006, www.foxnews.com/. Accessed 5 December 2017.

23 Horton, Alex. Army of Dude, 2006, www.armyofdude.blogspot.co.uk/. Accessed 27 November 2017.

24 David Stanford (ed.). The Sandbox, 2006, www.gocomics.typepad.com/the_sandbox/2006/10/index.html. Accessed 26 February 2018.

25 Matthew Currier Burden, Blackfive, www.blackfive.net/main/. Accessed 26 February 2018.

26 Salam Pax. 'June 27, 2003.' Salam Pax: The Baghdad Blogger, 27 June 2003, www.salampax. wordpress.com/. Accessed 30 November 2017.

27 See Lytle, Tatum H. 'A Soldier's Blog: Balancing Service Members' Rights vs. National Security Interests.' Federal Communications Law Journal 59 (2007) 593-614.

28 For further discussion of the specific legal framework, and debates about it, in the context of the war in Iraq, see Benevisti, Eyal. The International Law of Occupation. Oxford: Oxford University Press, 2012.

29 Resteigne, Delphine. 'Still connected in Operations? The Milblog Culture.' International Peacekeeping 17:4 (2010) 515-525 (521).

30 Hellman, Maria. 'Milblogs and soldier representations of the Afghanistan War.' Media, War and Conflict 9:1 (2016) 43-57 (44).

31 Blackfive. 'Tenets.' BlackFive, 2003, www.blackfive.net/main/. Accessed 5 March 2018.

32 Lewis, 'My Fork.' The Sandbox, 30 October 2006. www.gocomics.typepad.com/the_sandbox/2006/10/index.html. Accessed 26 February 2018.

33 Moja. '9.12.2003.' Turning Tables, 12 September 2003, www.turningtables.blogspot. co.uk/. Accessed 30 November 2017. 
34 See Munksgaard, Daniel. Warblog without end: Online anti-Islmamic discourses as persuadables. PhD thesis: University of Iowa, 2010.

35 Sacrificial Lamb. 'The Iraqi Army.' The Sandbox, 27 October 2006, www.gocomics.typepad.com/the_sandbox/2006/10/index.html. Accessed 26 February 2018.

36 Resteigne, 'Still connected...' (523-524).

37 Brant, Martha. 'War on Milblogs.' Newsweek, 8 August 2005 (8).

38 Schachtman, Noah. 'Army Squeezes Soldier Blogs, Maybe to Death.' Wired, 2 May 2007.

39 Ibid. 'New Army Rules Could Kill GI Blogs (Maybe Email, Too).' Wired, 2 May 2007.

40 Schwabb, Nikki, 'Milbloggers Wary of New Policy.' Washington Post, 5 May 2007.

41 Caldwell, Bill. 'Changing the Organisational Culture (Update).' Small Wars Journal, 3 February 2008, www.smallwarsjournal.com/. Accessed 4 December 2017.

42 Schachtman. 'Top General: Let Soldiers Blog.' Wired, 31 January 2008.

43 Alvarez, Steven J. Selling War: A Critical Look at the Military's PR Machine. Omaha: Potomac Books, 2016 (57).

44 Ibid (62).

45 Spektor, 'Cry Bias, and Let Slip the Blogs of War.' Wall Street Journal, 26 July 2006.

46 Hockenberry, John. 'The Blogs of War.' Wired, 1 August 2005.

47 Bowman and Willis, 'WeMedia' (7).

48 Gupta, Imagining Iraq (177).

49 See Benaissa, Amal, Blog.gov: 'Winning Digital Hearts E $\mathcal{E}$ Minds? Professionalization, personalization and ideology in foreign policy communication. PhD thesis: London School of Economics, 2011.

50 Hennessy, Cari Lynn and Paul S Martin. 'Blogs, the Mainstream Media, and the War in Iraq.' Paper prepared for presentation at the Annual Meeting of the American Political Science Association, Philadelphia, PA, 2006 (43).

51 See Sontag, Susan. On Photography. New York: Farrar, Straus \& Giroux, 1977, as well as George H. Roeder Jr.'s The Censored War: American Visual Experience During World War Two. New Haven: Yale University Press, 1993 for discussions of photography as a medium for representing truth.

52 Hider, James, 'Milblogs: telling it like it is on the front line.' The Times, 11 October 2004 (31).

53 See Johnson, Thomas J. and Barbara K. Kaye. 'Believing the blogs of war? How blog users compare on and characteristics in 2003 and 2007.' Media, War and Conflict 3:3 (2010) 315-333 for an account of how perceptions of blogs shifted over time.

54 'Soldier 'bloggers' report on war.' CNN.com, 26 March 2003, www.edition.cnn.com/2003/ WORLD/meast/03/26/sprj.irq.soldier.blogs.reut/. Accessed 6 December 2017.

55 Knickerbocker, Brad. 'Soldier blogs bring the front line to folks at home.' The Christian Science Monitor, 19 April 2005.

56 Dao, James. 'Military Blogging Goes Mainstream.' New York Times, 1 May 2011.

57 Wolf, Hope. 'Mediating War: Hot Diaries, Liquid Letters and Vivid Remembrances.' Life Writing 9:3 (2012) 327-336 (328).

58 Bowman and Willis, 'WeMedia' (25).

59 See Usbeck, Frank. "'Keep the Fan Mail Coming”: Ceremonial Storytelling and Audience Interaction in a US Soldier's Milblog.' Saechsische Landesbibliothek-Staats- und Universitaetsbibliothek Dresden 2016, 149-163.

60 Brennen, Bonnie and J. Scott Brennen. 'Taking Our Pictures: Citizen photojournalism in traditional U.S. News media.' Journalism Practice 9:4 (2015) 520-535 (521).

61 Yon, Michael. Michael Yon Online Magazine. 2004, www.michaelyon-online.com/MichaelYon/Michael-s-Dispatches/. Accessed 5 March 2018.

62 Friedersdorf, Conor. 'Why So Many Early Bloggers Got the Iraq War Wrong.' The Atlantic, 20 March 2013. 
63 Riverbend. 'The Opposite Direction.’ Baghdad Burning, 28 August 2003, www.riverbendblog.blogspot.co.uk/. Accessed 30 October 2017.

64 Hamilton, 'Best of the War Blogs', Time, Sunday 20 March 2003.

65 'At War: Notes from the Frontlines.' New York Times, 2015, www.atwar.blogs.nytimes. com/. Accessed 27 November 2017.

66 Riverbend. 'And We're Back.' Baghdad Burning, 21 July 2004, www.riverbendblog. blogspot.co.uk/. Accessed 30 October 2017.

67 BlackFive, quoted in Spektor, 'Cry Bias', 2006.

68 Feigel, Lara. The Bitter Taste of Victory: Life, Love and Art in the Ruins of the Reich. London: Bloomsbury, 2016 (96).

69 Lewis. 'My Fork.' The Sandbox, 30 October 2006, www.gocomics.typepad.com/the_sandbox/2006/10/index.html. Accessed 26 February 2018.

70 Ibid. 'Removing a Blockage.' Training for Eternity, 2 February 2006, www.chaplain. blogspot.co.uk/. Accessed 8 January 2018.

71 Moja. '9.12.2003.' Turning Tables, 12 September 2003, www.turningtables.blogspot. co.uk/. Accessed 30 November 2017.

72 Al-Ali, Nadje, and Deborah Al-Najjar. 'Writing Trauma, Memory, and Materiality.' In: AlAli and Al-Najjar (eds.), We Are Iraqis: Aesthetics and Politics in a Time of War. Syracuse: Syracuse University Press, 2013, xxv-xl (xxxviii).

73 See Thompson, Garry. 'Weblogs, warblogs, the public sphere, and bubbles.' Transformations: Journal of Media E Culture 2003, 1-11 (7).

74 Riverbend. 'Tales from Abu Ghraib.' Baghdad Burning, 29 March 2004, www.riverbendblog.blogspot.co.uk/. Accessed 30 October 2017.

75 Ibid. 'Turning Tables.' Baghdad Burning, 12 September 2003, www.riverbendblog. blogspot.co.uk/. Accessed 27 November 2017.

76 Moja. '10.15.2004.' Turning Tables, 12 September 2003, www.turningtables.blogspot. co.uk/. Accessed 30 November 2017.

77 Horton, 'The Ides of March.' Army of Dude, 20 March 2011, www.armyofdude.blogspot. co.uk/. Accessed 27 November 2017.

78 Levine, Adel. 'Combat Amputees, and Their Therapists, Find Roads to Happiness.' At War: Notes from the Frontlines. New York Times, 5 January 2016.

79 Lowndes, Sarah. The DIY Movement in Art, Music and Publishing: Subjugated Knowledges. London: Routledge, 2016 (261).

80 Hellman 2016 (54-56).

81 Horton. 'Bring it In!' Army of Dude, 8 November 2010, www.armyofdude.blogspot.co.uk/. Accessed 27 November 2017. Emphasis in original.

82 Dao 2011.

83 Riverbend. 'Ten years on...' Baghdad Burning, 9 April 2013, www.riverbendblog.blogspot. co.uk/. Accessed 30 October 2017.

84 Whether or not Facebook, etc. should be considered a platform or a publisher remains legally and culturally unresolved, but the public debate seems to be shifting towards the latter.

85 Dean, Jodi, Jon W. Anderson and Geert Lovink. Reformatting Politics: Information Technology and Global Civil Society. New York: Taylor and Francis, 2006 (22-23). 